Reprod. Nutr. Dévelop. 1980, 20 (1 A), 155-161.

\title{
Jejunal calcium permeability in laying hens during egg formation
}

par Y. NYS, P. MONGIN

Station de Recherches Avicoles, I.N.R.A.

Nouzilly, 37380 Monnaie, France.

Summary. The permeability of the upper jejunum to water, calcium, potassium, sodium and chloride was measured in the immature pullet and then in the laying hen before and during egg-shell calcification by an in vivo perfusion procedure. Jejunal calcium permeability was constant throughout egg formation. Thus, the increase of net absorption during shell calcification was not due to enhanced mucosal capacity for calcium translocation, but rather to a better solubilization of calcium carbonate in the upper digestive tract. However, this capacity increased at the onset of egg production, as shown by the difference between immature and mature birds.

\section{Introduction.}

Calcium absorption in the small intestine varies at sexual maturity and during egg-shell formation in the laying hen (Hurwitz ef al., 1973). Bar and Hurwitz (1972) have shown that its increase at maturity and at the onset of egg production is correlated with the concentration of calcium-binding protein ( $\mathrm{CaBP}$ ) in the duodenum. However, CaBP does not vary in that organ during the laying cycle, whereas calcium absorption almost doubles during egg-shell formation as compared to the status of no shell deposition (Bar and Hurwitz, 1975 ; Hurwitz and Bar, 1965 ; ltoh, 1967). In the first physiological situation, it seems logical that vitamin $D$ and its metabolites would be involved in the regulation of calcium absorption, according to the classical model already described in chickens and rats (Haussler and Mc Cain, 1977). However, such a model apparently does not fit egg-shell formation in the laying hen, and another explanation must be found.

If, a priori, calcium translocation through the gut is a passive mechanism, the changes observed may be imputed to two main causes : (i) the force(s) driving calcium through the mucosa may increase, and (ii) for a given driving force, the passive permeability of the mucosa barrier to calcium may also augment. In both cases, calcium absorption would be greater. However, the non-absorbable indicator method used by Hurwitz and Bar, and the ${ }^{45} \mathrm{Ca}$ retention method used by ltoh, measure net absorption, and thus they cannot evaluate the respective roles of mucosa permeabllity and of the calcium gradient between the lumen and the plasma. Several observations support a role for the latter. Hydrochloric acid secretion in the proventriculus has 
been found to increase during shell formation (Mongin, 1976b), and this secretion could enhance the dissolution of dietary calcium carbonate, thus elevating the calcium concentration in the liquid phase of the gut content. Mongin (1976a) confirmed this hypothesis, demonstrating that the calcium gradient through the mucosa increases during egg-shell formation.

In order to determine whether mucosal permeability also varies, the upper jejunum (the main site of calcium absorption : Hurwitz et al., 1973) was perfused in vivo before and during egg-shell calcification to estimate the passive calcium permeability of the mucosa. To test the method used, pullets were also perfused just before the onset of egg production when mucosal CaBP concentration and Ca absorption were low as compared to those of the laying bird.

\section{Material and methods.}

Birds. - The experiments were conducted on individually caged midweight laying hens (Warren). Twelve to 14-month old animals were used in the first trial, and 8 to 10 -month old ones in the second trial. They had free access to water and were fed a commercial diet ad libifum containing 3.5 p. 100 of $\mathrm{Ca}$. The poultry house was air-conditioned (temp. $20 \pm 1^{\circ} \mathrm{C}, \mathrm{RH} 60 \pm 5$ p. 100) and equipped with an automatic oviposition recording system. The lighting schedule was $16 \mathrm{hrs}$ of light and $8 \mathrm{hrs}$ of darkness. In the first trial, one group of 6 birds was perfused just after oviposition when no shell calcification was in progress, and a second group of 6 birds was used 14 to $30 \mathrm{hrs}$ later during egg calcification. In a second trial ( 8 birds), the perfusion started 3 to $5 \mathrm{hrs}$ before the onset of calcification and lasted 7 to $8 \mathrm{hrs}$ in order to detect any modification, in a given bird, resulting from the start of calcification. Four immature pullets was also used just before the onset of egg production.

Experimental procedure. - The birds were prepared for perfusion under Nembutal (trial 1) or Halothane (trial 2) anesthesea. The abdominal cavity was opened by lateral incision, and the upper jejunum tied off and cannulated $2-3 \mathrm{~cm}$ distal to the biliary duct and $20 \mathrm{~cm}$ before the diverticule of Meckel ; the length thus perfused was $21.4 \pm 4.9 \mathrm{~cm}$ for trial 1 , and $27 \pm 5.2 \mathrm{~cm}$ for trial 2 . The abdominal cavity was closed by suturing the muscle and skin separately. A wash period with warm physiological serum was followed by a 45 to 60 -min equilibration period permitting a return to steady state. The jejunal segment was perfused by a peristaltic pump at a constant rate of $0.6 \mathrm{ml} \times \mathrm{min}^{-1}$. The effluent fluid was collected every $30 \mathrm{~min}$ by gravity drainage. The basic perfusion liquid used in trial 1 contained $\left(\mathrm{mM} \times 1^{-1}\right): \mathrm{KH}_{2} \mathrm{PO}_{4}: 2$; $\mathrm{MgSO}_{4}, 7 \mathrm{H}_{2} \mathrm{O}: 2 ; \mathrm{KCl}: 40 ; \mathrm{NaCl}: 0 ; \mathrm{CaCl}_{2}: 4-12.5$ or 20 (2 birds per concentration and physiological stage). Each bird was perfused with three solutions having the same solute concentration but different osmolarify adjusted to 200,350 or 500 mosm by adding raffinose.

In the second experiment, the perfusion solution was as follows $\left(m M \times 1^{-1}\right)$ : $\mathrm{KH}_{2} \mathrm{PO}_{4}: 2 ; \mathrm{MgSO}_{4}, 7 \mathrm{H}_{2} \mathrm{O}: 2 ; \mathrm{KCl}: 23 ; \mathrm{NaCl}: 30 ; \mathrm{CaCl}_{2}: 12.5$ or 20 (4 birds per concentration). The osmotic pressure was maintained constant at 350 mosm $\times 1^{-1}$.

Radioactive polyethylene glycol (PEG 4000) was used as volume marker $(10 \mu \mathrm{Ci}$ and $3.3 \mathrm{~g}$ cold PEG $\mathrm{I}^{-1}$ ) (Bindler and Skadhauge, 1971). 
Chemical assays. - All chemical analyses were done in duplicate on both initial perfusion fluids and final effluent perfusates. Sodium and potassium were determined by flame photometry (Radiometer FLM 2) and chloride by chloridometry (Radiometer CMT 10). Calcium was determined by EGTA titration under ultraviolet light using calcein as an indicator. Osmotic pressure was measured in a Fiske osmometer. $P E G{ }^{14} \mathrm{C}$ was counted in a Nuclear Chicago liquid scintillation spectrophotometer. The scintillation fluid was toluene-triton X-100 (2:1) with PPO $\left(4 \mathrm{~g} \mathrm{I}^{-1}\right)$ and POPOP $\left(0.05\right.$ g $\left.\mathrm{I}^{-1}\right)$.

Calculation. - The following equations were used:

Net water absorption $\mathrm{J} v=\mathrm{Vin}-\mathrm{Vout}-\Delta \mathrm{V}_{\mathrm{i}}$

$\Delta V_{i}=2 \frac{\sum M_{i-1}}{\text { PEGin }+ \text { PEGout }}-2 \frac{\sum M_{i-1}}{\text { PEGin }+ \text { PEGout }}$

Net soluble flux Js $=$ Vin Sin - Vout Sout $-\Delta V_{i}\left(\frac{\operatorname{Sin}+\text { Sout }}{2}\right)$

where Vin and Vout are, respectively, the volumes of solution entering and leaving the perfused organ over a given time period, $\Delta V_{1}$ is the variation of the dead space volume, PEGin and PEGout the PEG ${ }^{14} \mathrm{C}$ concentration in the solution flowing in and out, $\sum M_{i}$ the total PEG ${ }^{14} \mathrm{C}$ cumulated in the dead space from the beginning of the study, and Sin and Sout the solute concentrations. A positive net flux (absorption) denoted a net movement from the mucosal to the serosal compartments and vice versa. The data for JV and Js were expressed in terms of $\mathrm{ml} \times \mathrm{hr}^{-1}$ and $\mu \mathrm{eq} \times \mathrm{hr}^{-1}$ per gram of dry mass perfused jejunum ; for example, $1 \mathrm{~g}$ of DM jejunum was equivalent to about $12.3 \mathrm{~cm}$ and $3.7 \mathrm{~g}$ of wet weight tissue.

\section{Results.}

As shown in a comparison of the means in table 1, egg-shell calcification did not change the net fluxes of water and minerals. It could be argued that variability bet-

TABLE 1

Experiment 1. - Effect of egg-shell formation on net water and solute fluxes through the upper jejunum

Physiological stage

$\begin{array}{lll}\text { Water } & \mathrm{Ka}^{++} & \mathrm{Na}^{+} \\ \left(\mathrm{ml} \mathrm{h}^{-1} \mathrm{~g} \mathrm{DM}^{-1}\right) & \left.\mathrm{Ca}^{-1} \mathrm{~g} \mathrm{DM}^{-1}\right)\end{array}$

Without egg-shell forma-

tion (6) ............

With egg-shell formation

(6) $\ldots \ldots \ldots \ldots \ldots \ldots$

$F(1,6) \quad \ldots \ldots \ldots \ldots \ldots$

$\begin{array}{ccccc}-2.35 \pm 0.62\left({ }^{a}\right) & 104 \pm 12 & 191 \pm 15 & -816 \pm 55 & -540 \pm 50 \\ -1.71 \pm 0.56 & 85 \pm 11 & 169 \pm 14 & -760 \pm 33 & -465 \pm 46 \\ 0.24 & 1.71 & 0.34 & 0.25 & 0.56\end{array}$

(a) Mean \pm SEM, a positive net flux denotes a net flux from the muscosal to the serosal compartments.

( ) Number of birds. Different groups of birds were used in each trial. 
ween birds might hide the process we were studying, but as seen in table 2, water and solute fluxes were clearly unmodified by egg-shell mineral deposition when measured in the same bird a few hours before and after the onset of calcification.

TABLE 2

Experiment 2. - Net water and solute fluxes through the upper jejunum measured on the same bird just before and after the beginning of shell calcification

\begin{tabular}{cccccc}
\hline Physiological stage & $\left.\begin{array}{c}\text { Water } \\
(\mathrm{ml} \mathrm{h}-1\end{array} \mathrm{gM}^{-1}\right)$ & $\mathrm{Ca}^{++}$ & $\left.\begin{array}{c}\mathrm{K}^{+} \\
(\mu \mathrm{eq} \mathrm{h}\end{array} \mathrm{h}^{-1} \mathrm{~g} \mathrm{DM}^{-1}\right)$ & $\mathrm{Cl}^{-}$ \\
\hline $\begin{array}{c}\text { Before egg-shell deposi- } \\
\text { tion (8) } \ldots \ldots \ldots \ldots \ldots\end{array}$ & $-2.32 \pm 0.24(a)$ & $144.5 \pm 13$ & $143 \pm 10$ & $-555 \pm 31$ & $-207 \pm 34$ \\
$\begin{array}{c}\text { During egg-shell depo- } \\
\text { sition (8) } \ldots \ldots \ldots \ldots .\end{array}$ & $-2.28 \pm 0.52$ & $144 \pm 11$ & $152 \pm 7$ & $-556 \pm 74$ & $-215 \pm 87$ \\
$\mathrm{~F}(1.6) \ldots \ldots \ldots \ldots \ldots$ & 0.003 & 0.08 & 2.5 & 0 & 0 \\
\hline
\end{tabular}

(a) See legend table 1.

We checked the immaturity of the pullets before the beginning of laying by their total plasma calcium content $\left(120 \mathrm{mg} \times \mathrm{l}^{-1}\right)$. Under these conditions, and whatever the calcium concentration in the lumen, calcium absorption was always reduced in immature birds (table 3).

TABLE 3

Net flux of calcium through the upper jejunum in laying and immature birds

\begin{tabular}{|c|c|c|c|}
\hline \multirow{2}{*}{$\begin{array}{l}\text { Calcium concentration in } \\
\text { the perfused solution }\end{array}$} & \multicolumn{2}{|c|}{ Laying bird } & \multirow{2}{*}{ Immature birc } \\
\hline & First trial & Second trial & \\
\hline $\begin{array}{l}25 \text { meq } I^{-1} \ldots \ldots \ldots \ldots \ldots \ldots \\
40 \text { meq } I^{-1} \ldots \ldots \ldots \ldots \ldots \ldots\end{array}$ & $\begin{aligned} 89 & \pm 10\left(^{(a)}\right. \\
150 & \pm 22\end{aligned}$ & $\begin{aligned} 98 & \pm 10(4) \\
191 & \pm 11\end{aligned}$ & $\begin{array}{l}10 \pm 3.3 * *(3) \\
57 \pm 4.8 * *\end{array}$ \\
\hline
\end{tabular}

(a) Mean + SEM in $\mu$ eq $\times \mathrm{h}^{-1} \mathrm{~g}^{-1}$ of DM.

() Number of animals.

** Significantly different from laying bird $(P<0.01)$.

In one bird perfused a few days before ovulation of the first egg (as judged by the maturity of the ovary and its plasma calcium), the calcium flux was $133 \pm 8$ $\mu$ eq $\times h^{-1} \times g^{-1}$ DM for a concentration in the perfused solution equal to 40 meq $\times \mathrm{I}^{-1}$.

\section{Discussion.}

Kenny (1976) studying the Japanese quail, suggested that the increased calcium absorption occurring during egg formation could be due to enhanced production of 
1-25 dihydroxycholecalciferol (1-25 DHCC). In fact, he observed a peak of 25-hydroxycholocalciferol-1 hydroxylase activity in kidney homogenates at the time of ovulation and a reduction in activity when no egg was present in the oviduct.

More recent results have indicated that the temporal pattern of this enzymatic activity and that of calcium absorption are not in phase. A reduction of 1-hydroxylase activity is only observed $20 \mathrm{hrs}$ after the oviposition of the last egg of the clutch, while already at $2 \mathrm{hrs}$ after oviposition calcium absorption is one-third of that prevailing during shell calcification (Montecuccoli et al., 1977). Furthermore, there is ninefold more 1-25 DHCC in the laying hen than in the non-laying control (Spanos et al., 1976), but in birds having a pause of one day only, 1-25 DHCC remains the main vitamin D metabolite, whereas 24-25-DHCC prevails in the non-laying hen (Sedrani and Taylor, 1977).

Finally, the lack of variation of CaBP concentration in the duodenum and jejunum during egg-shell formation (Bar and Hurwitz, 1975) is also consistent with the idea that vitamin $D$ is not involved in cycle calcium absorption during shell calcification.

The present results show that when calcium concentration is imposed in the intestinal lumen, a diurnal change in net calcium absorption is not observed. It can therefore be concluded that an enhanced gut capacity for calcium absorption at the time of shell mineralization is not the cause of the increased calcium absorption, and hence that the idea of a modification in the passive Ca permeability of the jejunal mucosa must be discarded.

An alternative way to explain these changes in net calcium absorption is by variations in the driving forces involved. Calcium concentration gradient is one such force, as shown in table 3, and apparently a main one (Nys and Mongin, unpublished data). In fact, modifications in the composition of the liquid content of the upper intestine have been observed previously (Mongin, 1976a, b). The mean calcium concentration in the duodenum and upper jejunum ranges between 10 to $15 \mathrm{meq} / \mathrm{l}$ without eggshell deposition, and increases generally up to $50-60 \mathrm{meq} / \mathrm{l}$ during egg-shell formation (Mongin, unpublished data).

Furthermore, if the ability of the laying bird to ingest more calcium just before egg calcification is considered (Mongin and Sauveur, 1974) together with the alteration of digestive tract motility (Roche and Decerpit, 1977), such an hypothesis seems more plausible.

Recent observations of Bar et al. (1976) are consistent with our data. They reported that Japanese quails fed synthetic $1 \alpha$-hydroxycholecalciferol $(1 \alpha-\mathrm{HCC})$ absorbed calcium better than those fed a vitamin D3 diet. The changes during the laying cycle were not only maintained, but amplified, by $1 \alpha-\mathrm{HCC}$. This enhanced daily variation in net absorption was the result of long-term improvement of the calcium absorption capacity induced by $1 \alpha-\mathrm{HCC}$. However, this mechanism was fully operative only when there was a sufficient amount of solubilized calcium. Here, it is worthwhile to note that not only calcium, but potassium, absorption shows daily variations (Taylor and Kirley, 1967 ; Nys, 1979).

It is concluded that the hourly regulation of calcium absorption in laying hens is governed by the action of several factors in the upper digestive tract modifying the 
solubility of calcium carbonate. This does not exclude a possible modification of endogenous Ca secretion, as proposed by Wasserman and Combs (1978), but it would lake place in the segments distal to the upper jejunum.

Reçu en juin 1979.

Accepté en juillet 1979.

Acknowledgments. - We wish to thank $X$. de Laage for his advice on the procedure.

Résumé. Nous avons mesuré sur des poulettes immatures et sur des poules pondeuses, juste avant et pendant la calcification de l'œuf, la perméabilité de la muqueuse jejunale à l'eau, au calcium, potassium, sodium et chlore par une méthode de perfusion in vivo. La perméabilité jejunale, notamment calcique, ne varie pas au cours du cycle de formation de l'œuf. L'augmentation de l'absorption nette de Ca observée pendant la calcification de l'œuf ne semble donc pas due à une modification de la capacité de transport de la muqueuse intestinale. Elle résulterait plutôt d'une meilleure solubilisation du carbonate de Ca dans l'intestin proximal. Par contre, cette capacité de transfert chez la poule mature est plus importante que celle de la poulette immature.

\section{References}

BAR A., HURWITZ S., 1972. Relationship of duodenal calcium-binding protein to calcium absorption in the laying fowl. Comp. Biochem. Physiol., 41b, 735-744.

BAR A., HURWITZ S., 1975. Intestinal and uterine calcium-binding protein in laying hens during different stages of egg formation. Poult. Sci., 54, 1325-1327.

BAR A., EISNER U., MONTECUCCOLI G., HURWITZ S., 1976. Regulation of intestinal calcium absorption in the laying quail : independant of kidney vitamin $D$ hydroxylation. J. Nutr. 106, 1336-1342.

BINDSLEV N., SKADHAUGE E., 1971. Salt and water permeability of the epithelium of the coprodeum and large intestine in the normal and deshydrated fowl in vivo perfusion studies. $J$. Physiol., 216, 735-751.

HAUSSLER M. R., MC CAIN T. A., 1977. Basic and clinical concepts related to vitamin D metabolism and action. New Engl. J. Med., 297, 974-983 and 1041-1050.

HURWITZ S., BAR A., 1965. Absorption of calcium and phosphorus along the gastrointestinal tract of the laying fowl as influenced by dietary calcium and eggshell formation. J. Nutr., 86, 433438.

HURWITZ S., BAR A., COHEN I., 1973. Regulation of calcium absorption by fowl infestine. Am. J. Physiol., 225, 150-154.

ITOH H., 1967. Calcium metabolism in laying hens (v). Jap. J. Zoot. Sci., 38, 507-513.

KENNY A. D., 1976. Vitamin D metabolism : physiological regulation in egg-laying Japanese quail. Am. J. Physiol., 230, 1609-1615.

MONGIN P., SAUVEUR B., 1974. Voluntary food and calcium intake by the laying hen. Br. Poult. Sci., 15, 349-359.

MONGIN P., 1976a. Ionic constituents and osmolality of the small intestinal fluids of the laying hen. Br. Poult. Sci., 17, 383-392.

MONGIN P., 1976b. Composition of crop and gizzard contents in laying hen. Br. Poult. Sci., 17, 499. 507.

MONTECUCCOLI G., HURWITZ S., COHEN A., BAR A., 1977. The role of 25-hydroxycholecalciferol-1-hydroxylase in the responses of calcium absorption to the reproductive activity in birds. Comp. Biochem. Physiol., 577, 335-339.

NYS Y., 1979. Influence de l'heure d'un repas unique sur la retention de $\mathrm{Ca}, \mathrm{K}$ et $\mathrm{P}$ et sur l'index de coquille chez la poule pondeuse. Ann. Biol. anim. Bioch. Biophys., 19, 983-988. 
ROCHE M., DECERPIT J., 1977. Contrôles hormonal et nerveux de la motricité du tractus digesti de la poule. Ann. Rech. vét., 8, 25-40.

SEDRANI S., TAYLOR T. G., 1977. Metabolism of 25-hydroxycholecalciferol in Japanese quail in relation to reproduction. J. Endocr., 72, 405-406.

SPANOS E., PIKE J. N., HAUSSLER M. R., COLSTON K. W., EVANS I. M. A., GOLDNER A. M., MC CAIN T. A., MC INTYRE I. V., 1976. Circulating I, 25 hydroxyvitamin D in the chicken: enhancement by injection of prolactin and during egg laying. Life Sci., 19, 1751-1756.

TAYLOR T. G., KIRLEY J., 1967. The absorption and excretion of minerals by laying hens in relation to egg-shell formation. Br. Poult. Sci., 8, 289-295.

WASSERMAN R. H., COMBS J. R., 1978. Relation of vitamin D-dependent calcium binding protein to calcium absorption during the ovulatory cycle in the Japanese quail. Proc. Soc. exp. BiolMed., 159, 286-287. 